\title{
O A VIRUS THAT CAN ACTUALLY SAVE US FROM HARM!
}

DR KARYNA ROSARIO IS BASED WITHIN THE MARINE GENOMICS LABORATORY AT THE UNIVERSITY OF SOUTH FLORIDA IN THE US. HER RESEARCH, FOCUSING ON VIRAL METAGENOMICS, HAS LED TO THE DISCOVERY OF A NOVEL INDICATOR THAT HELPS DETECT HARMFUL PATHOGENS IN WASTEWATER. THE FINDINGS WILL LEAD TO SAFER LIVES FOR ALL OF US

Human enteric pathogens are microbes that affect the intestine and can make people unwell. Most of us will have heard of E. coli and salmonella, which are enteric pathogens often found on food products that have not been prepared adequately, but there are many more that can cause sickness, diarrhoea and even death. For that reason, human enteric pathogens are of interest to scientists, both in terms of identifying their presence and finding means of combatting them.

Dr Karyna Rosario is a marine scientist who has worked on just that. She is based within the Marine Genomics Laboratory at the University of South Florida in the US and her research has contributed to the development of strategies for effective microbial water quality monitoring and the assessment of wastewater treatment technologies. When we flush the toilet, many of us don't give a second thought to what happens to the water, but there are many pathogens in human excreta that can become present in domestic wastewater. This is potentially problematic, as domestic wastewater is ultimately released back into the environment and, if this water contains human pathogens, it could make people sick after coming into contact with it.

\section{WHAT METHODS ARE USED TO} DETERMINE THE PRESENCE OF PATHOGENS IN WASTEWATER?

E. coli is an example of faecal indicator bacteria (FIB). The presence of FIB in a sample of wastewater suggests the presence of pathogens that have originated from faecal matter.

"Historically, FIB have been used to determine the microbial quality of water samples worldwide because they are affordable and easy to test," explains Karyna. "Unfortunately, FIB detection (or lack thereof) does not necessarily tell us anything about the presence of actual human pathogens and/or health risks associated with a given water resource. This is particularly true for viruses, which are entirely different from bacteria." For these reasons, it is important that better indicators are developed, especially for waterborne viruses.

\section{HOW IS KARYNA WORKING TO} DEVELOP BETTER INDICATORS?

One of the most interesting outcomes of Karyna's research is the use of a virus to help identify the presence of human enteric pathogens. Her team noticed that the pepper mild mottle virus (known as PMMoV and present in common food items such as chili sauce) was abundant in wastewater and present in most of the samples that contained human pathogens of concern - this essentially means that if $\mathrm{PMMoV}$ is present at certain levels in a given sample, it is an indicator that there might be a risk of becoming sick if precautions are not taken.

\section{WHAT ARE THE ADVANTAGES OF} USING PMMOV AS A SURROGATE

\section{VIRAL INDICATOR?}

Karyna's mentor and PhD advisor, Dr Mya Breitbart, had done some previous work that showed PMMoV is really abundant in excreta from healthy individuals. Then, when Karyna looked at viruses in reclaimed water (the reusable end product of wastewater treatment) for her PhD project, she found PMMoV makes it through the treatment. "We wondered if PMMoV could be used as a viral indicator of human faecal pollution and started looking at $\mathrm{PMMOV}$ in wastewater and environmental samples," explains Karyna. "PMMoV is a plant- 


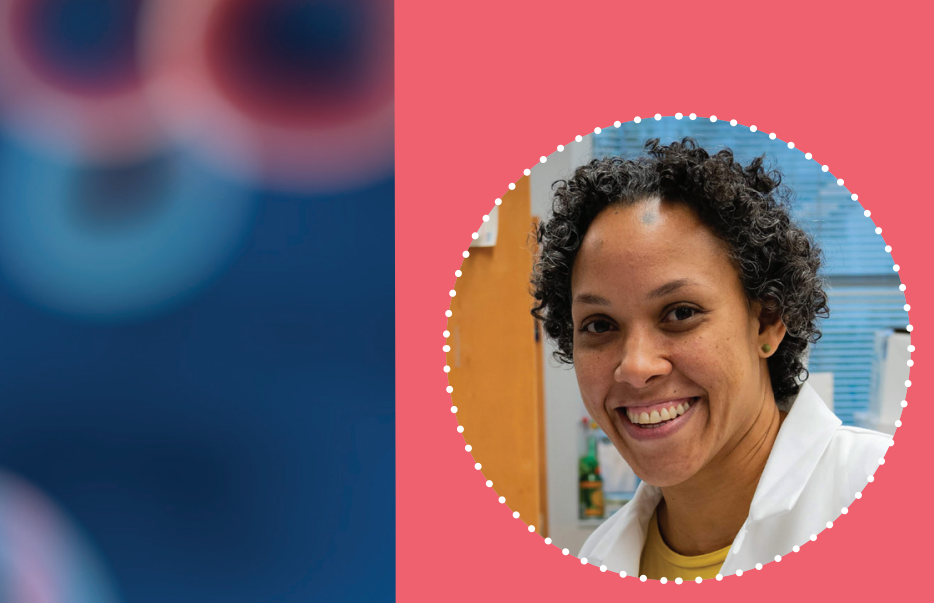

DR KARYNA ROSARIO

College of Marine Science

University of South Florida USA

$\ldots \ldots \ldots \ldots$

FIELD OF RESEARGH

Marine Science

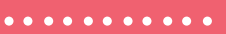

RESEARCH

Karyna's work identified the pepper mild mottle virus as an indicator of domestic wastewater pollution. The findings will lead to improvements in wastewater treatment and help humans lead healthier and safer lives.

..........

FUNDER

National Science Foundation

infecting virus rather than a human virus and, similar to FIB, it is not a health threat when working in the lab."

In addition, because PMMoV is dietary in origin, its concentration in wastewater does not depend on active infection of the population. "This is ideal because it is not practical to test for all enteric pathogens which may exhibit different dynamics and seasonality. For example, if we are testing for norovirus specifically, but there is a different viral infection in the population, we would completely miss that there are other pathogens in our samples," says Karyna. "PMMoV is found in high concentrations in wastewater, compared to other viral indicators or pathogens, and can be readily detected regardless of season."
HOW WILL THESE FINDINGS BE USED IN THE FUTURE?

Karyna is the first to admit that not everyone likes to talk about viruses, especially related to reclaimed water, and, initially, some community stakeholders were reticent to listen to her findings. Resilient and passionate about scientific endeavour, Karyna persisted in talking to people about her work. She was supported by her colleague, Dr Erin Symonds, who worked hard to encourage other researchers to incorporate $\mathrm{PMMOV}$ into their studies, and, of course, her mentor, Mya. The team is now hopeful that PMMoV will become part of the methods used to safeguard public health.

However, more work needs to be done on developing methods that are easier, faster and cheaper. "One of the limitations we face when detecting PMMoV is that we rely on molecular methods that are time-consuming and require highly trained or specialised individuals and equipment," says Karyna. "The good news is that PMMoV has been studied for a long time given that it is a plant virus that has threatened the agricultural sector for decades." Ultimately, this puts Karyna and the team at an advantage - techniques for PMMoV detection already exist, albeit in the agricultural sector. The plan is to take the learnings from there and adopt them for water quality purposes, which will benefit everyone and safeguard them against harmful viruses. 


\section{DA La La SCIENCE}

ABOUT MARINE SCIENCE

Marine science is the branch of science concerned with the sea. It is an extremely broad discipline and marine scientists can work in areas as diverse as marine biology, geology and geophysics, zoology and environmental protection. It is said that the history of marine biology might have begun as early as $1200 \mathrm{BC}$ when the Phoenicians took to the ocean, but it wasn't until Aristotle that references to marine life were recorded. Indeed, Aristotle is often referred to as the father of marine biology.

Captain James Cook mapped much of the world's unchartered waters in the 18th century, while Charles Darwin went on several expeditions on the HMS Beagle from 1831 to 1836 . This led to the publication of the Origin of Species, where his theories of natural selection and evolution were formulated. These days, marine scientists tend to be more focused on specific research aims, including Karyna who uses molecular techniques to identify viruses in environmental samples.

\section{WHAT DOES KARYNA FIND MOST} REWARDING ABOUT HER WORK? Karyna specialises in a technique called viral metagenomics, which allows her to target all the genetic material from viruses found in any given sample. By circumventing techniques that target specific viruses, such as the polymerase chain reaction (PCR), Karyna's research has often led to the discovery and detection of unsuspected viruses. She explains, "PCR is like fishing one fish at a time, using bait that works for certain types of fish, whereas viral metagenomics is like using a giant net you never know which 'fish' you're going to catch!"

She enjoys hunting for viruses in a variety of environmental samples (from wastewater, to seawater, to air) and organisms (mainly invertebrates and plants) and says collaboration is one of the main appeals of her work. "I get to work with scientists from different backgrounds who are interested in learning about viruses in their study systems - it is always exciting to discover new viruses and contribute to new knowledge," says Karyna. "In addition to research, I really enjoy working with students in the lab and seeing them develop as scientists and professionals."

\section{WHAT ARE THE MOST SURPRISING} THINGS ABOUT VIRUSES?

With the shadow of the coronavirus pandemic still hanging over the world, the public is paying more attention to viruses than it has done for some time. It might be surprising for you to learn that viruses are by far the most abundant biological entities on our planet and they affect all living organisms. "In our oceans, there are about 100 billion times as many viruses as there are grains of sand on Earth - next time you go to the beach you can think of how you are swimming in viruses, but don't worry the majority of those infect microorganisms, not people," says Karyna. "I imagine most people don't get a warm feeling from such an image but it's worth knowing that there is an incredible diversity of viruses and there is much to learn about what they are doing."

\section{WHAT ARE THE MOST PRESSING}

ISSUES FACING TODAY'S MARINE

SCIENTISTS?

Karyna believes the most pressing issue is understanding the impacts of climate change on our oceans and designing mitigating strategies. "When we consider the trend of 'alternative facts' and science denial, science communication is becoming more and more important," says Karyna. "Scientists need to lead efforts to communicate with the public and learn how to do it effectively." It is essential that more people become aware of the dangers of climate change and explore potential strategies to mitigate these impacts.

\section{HOW TO BECOME A MARINE SCIENHST}

- Career Explorer goes into great detail about the experience of being a marine biologist. From what they do, to the various job titles that fall within the field of marine science, through to some frequently asked questions, this website has it all. https://www. careerexplorer.com/careers/marine-biologist/

\section{- Stanford Libraries has a comprehensive list of} marine biology organisations and institutions in the US. Have a look through and head to the sites that are most specific to your particular interests. https://library.stanford.edu/hopkins/research-help/ marine-biology-organizations-and-institutions

- The average salary for a marine biologist in the United States is $\$ 32,159$. Wages typically start from $\$ 24,166$ and go up to $\$ 71,561$. https://www. careerexplorer.com/careers/marine-biologist/salary/

\section{PAHWAY FROM SGHOOL TO MARINESGIENGE}

Karyna thinks it is important to have a broad base of science and maths courses under your belt, including chemistry, physics, calculus, biochemistry and statistics. "It would be advantageous to have some basic understanding of coding/informatics given that many of the technologies used today either need or produce large amounts of data that require computing power for analysis and visualisation," says Karyna. "In addition to courses, I highly recommend seeking research experiences. Hands-on experiences will help you figure out what you do and don't enjoy."

2 or $3 \mathrm{~A}$ levels, or equivalent.

You will usually need a degree that is relevant to the specific area of marine science you want to work in. Possible subjects include biology, chemistry, ecology, marine biology, oceanography, physics and zoology.

https://www.careerexplorer.com/careers/marine-biologist

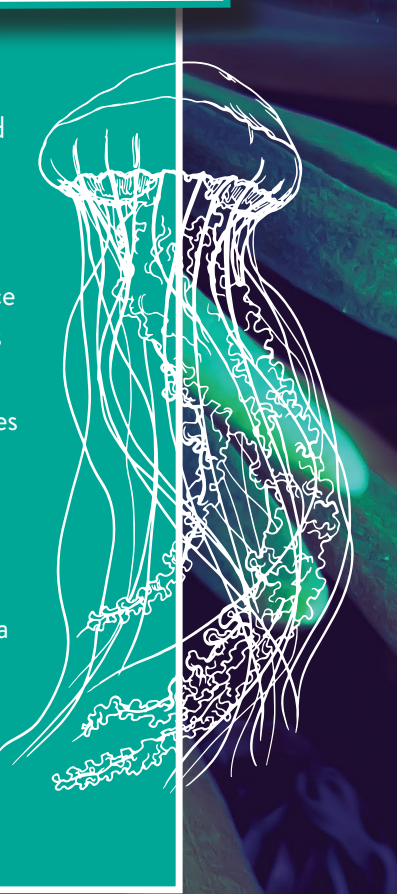




\section{0 HOW DID DR KARYNA ROSARIO BECOME A MARINE SCIENTIST?}

WHAT WERE YOUR INTERESTS AS A CHILD? DID YOU ALWAYS WANT TO BE A SCIENTIST?

Growing up, I loved being outdoors and was curious about animals and nature. I never really thought about becoming a scientist all I knew was that I really enjoyed biology, chemistry and genetics courses in school. I decided to enrol as a biotechnology major in college, where I found I still enjoyed science courses. After participating in a few research projects and learning about the microbial world, I was hooked forever!

WHO OR WHAT HAS INSPIRED YOU IN YOUR CAREER?

Over the years, I have been inspired by great mentors who are passionate about their science. There are too many to mention all of them, but what the following individuals have in common is a genuine interest in helping others succeed and, in one way or another, they gave me the tools (emotional and/or technical) to pursue a career in science. From my BS degree training I am thankful to Drs Vivian Navas
Almeyda, Carlos Ríos Velázquez and Brian L. Bingham. From my MS degree, my advisors: Dr Raina Maier and Julie Nielson. During my PhD I was fortunate to meet $\mathrm{Dr}$ Arvind Varsani, a friend and collaborator. Last but not least, I have had the pleasure of working with Dr Mya Breitbart, whom I consider a fierce and selfless scientist, mentor and friend, for over ten years.

WHAT DO YOU THINK ARE THE KEY SKILLS AND ATTRIBUTES THAT A SCIENTIST NEEDS TO BE SUCCESSFUL?

If you are curious and enjoy learning and figuring out how things work, I think science is for you. Other important aspects are a willingness to work in teams, selfmotivation, not being afraid of making mistakes and good communication skills.

WHAT AMBITIONS OR GOALS DO YOU HAVE?

We are living in strange times. As I write answers for this interview, there is a pandemic that threatens the life of every citizen around the world and climate change is quickly painting a dire scenario for future generations. I'm perplexed by the fact that some people think these pressing issues are hoaxes. The scientific endeavour is seemingly becoming less valued and respected. I hope to continue contributing to new knowledge with my research, while becoming a better advocate for bridging scientific discovery with the needs of our community.

HOW DO YOU SWITCH OFF FROM YOUR WORK?

When I am not working, I love spending time with family and playing with my sons. It doesn't matter what happens in the lab, good or bad, my boys just want to play, wrestle and run around! Being outdoors and exercising also helps me switch off from work.

\section{KARYNA'S TOP TIPS}

1 Try and discover what you find most exciting about your field of study as soon as you can and, once you have, never lose sight of it when things get complicated.

2 Studying and doing well in classes is important, but make sure you make room in your life for friends and family. They will support you in your quest for new life experiences. In my case, science facilitated new experiences that helped shape my academic and professional career, but family and friends have always remained important to me.

3 If you are interested in pursuing a career in science, please always keep in mind that there is no set path. Never count yourself out based on pre-conceived ideas of what a scientist's background should be!
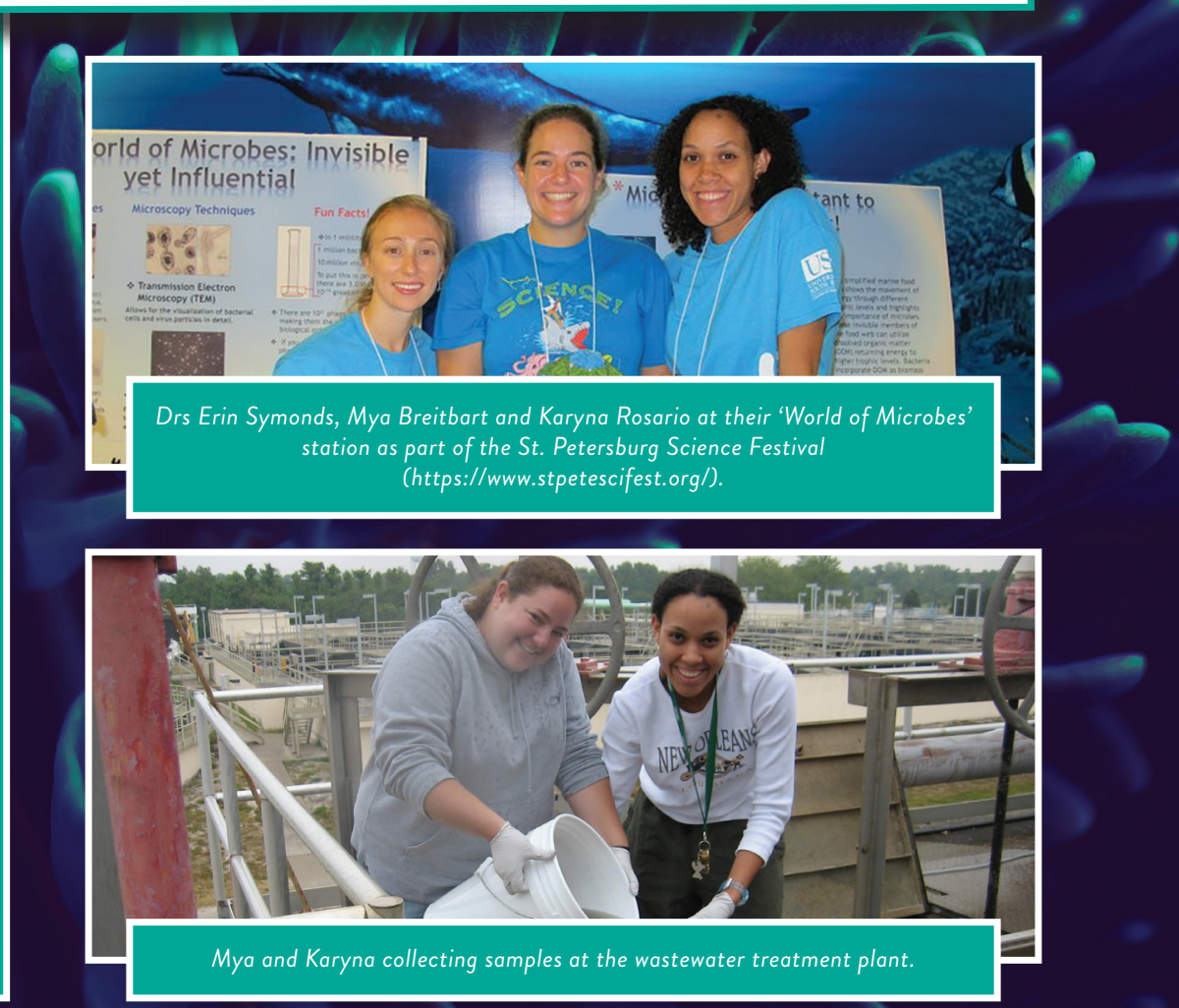